\title{
Factors Impacting on Reward Systems: A Comparative Study between Public and Private Universities in Zimbabwe
}

\author{
Nyanhete Tatenda ${ }^{1} \&$ Bhebhe Moment ${ }^{1}$ \\ ${ }^{1}$ Human Resource Management Department, Midlands State University, Gweru, Zimbabwe \\ Correspondence: Nyanhete Tatenda, Human Resource Management Department, Midlands State University, No \\ 21 Malvern road Lundi park, Gweru, Zimbabwe. Tel: 263-77-587-8534; 263-77-705-1817. E-mail: \\ nyanhetet@msu.ac.zw; mbhebhe@msu.ac.zw
}

\author{
Received: July 3, 2014 Accepted: July 14, 2014 Online Published: September 24, 2014 \\ doi:10.5539/jsd.v7n5p150 URL: http://dx.doi.org/10.5539/jsd.v7n5p150
}

\begin{abstract}
The aim of the research was to identify and compare the reward choices in the public and private sector and establishing the extent to which these choices were influenced by the environment. The research adopted both the quantitative and qualitative methodologies. Unstructured interviews, questionnaires and focus group discussions where used in data collection. Narrative and descriptive approaches where used in data presentation with the use of tables and matrixes to relate statistical data. The data was analysed using the thematic analysis. The major findings of the research indicated that the environment both internal and external that an organisation would be operating in did influence the reward choices. External environmental factors identified were politics, government, economic situation, sector, competition and the labour market. The internal factors were students, employees through employee associations, total costs of the organisation and management. Findings also showed that some factors of the environment affected the private and public sector differently thus resulting in different strategic choices for example the government. This confirmed the theoretical framework that reward choices were contingent upon the environment and that stakeholder concerns were taken into consideration when choosing strategies.
\end{abstract}

Keywords: reward choices, factors affecting, environment, public sector, private sector, universities, Zimbabwe

\section{Introduction}

In response to the emerging environmental pressure (highly dynamic, complex and competitive for qualified employees), higher learning institutions are transforming their structures and management systems. As a result, many universities are rethinking their reward strategies to better align them with the new realities in order to improve teaching staff motivation and retention (Workineh \& Zewdie). Reward management is concerned with the formulation and implementation of strategies and policies the purposes of which are to reward people fairly, equitably and consistently in accordance with their value to the organisation and to help the organisation to achieve its strategic goals (Armstrong, 2009) When making a strategic reward management choice organisations have to consider the relevant forces in the external environment that affect their reward strategy. As a result environmental variability has attracted most attention as the major factor for inducing adjustments to organisations' strategic rewards (Child, 2000). The organisation exists in the context of a complex and dynamic political, legal, economical, socio-cultural, technological and ecological world which affects these strategies.

Both public and private universities need to adopt and manage the diverse external and internal environmental factors that affect their sustainability because differences in these environments can be a distinguishing factor between public and private university strategic reward choices. A public university is a university that gets subsidies from the government to lower tuition costs. A private university is that university that is not publicly funded by the government so students must pay the full economic costs of their programmes of study. When coming up with rewards universities are faced with the task of considering the dynamic relationships between social contracts, industry standards, employee expectations, competitive imperatives, legal requirements, cultural and national diversity, to achieve organisational goals. The ability to respond to these changing circumstances is limited not only by resources but also by management philosophies and structures that characterise public and private sectors. 
Orientation profit and revenue

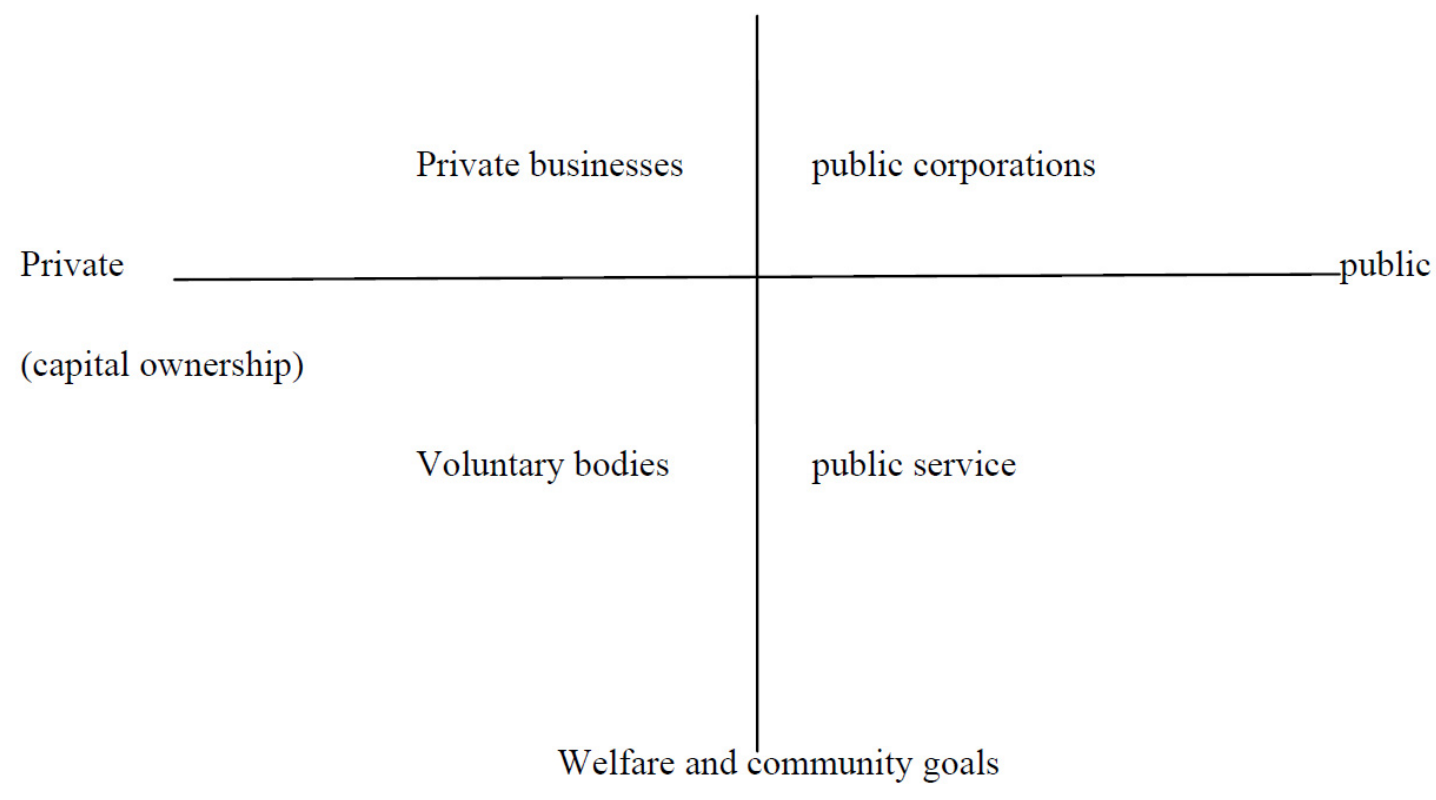

Figure 1. Organisation typology by orientation and ownership

Source: Farnham, personnel in context (ipm, 1990)

The above diagram reflects that an organisation's orientation and ownership determines the goals and objectives it will seek to achieve. The goals and objectives will inform the strategic reward choices made by an organisation in response to environmental changes. The strategic reward choices selected therefore depend on the sector whether public or private because the two sectors have different goals and objectives. The diagram shows that the public sector's goals are to satisfy citizen's needs within the community that is welfare (standards of living) and community goals (infrastructure development) and then revenue and profits but as for the private sector their objective is solely profit and revenue.

The private and public sectors in Zimbabwe are facing a plethora of challenges ranging from finding money for recapitalisation, motivating staff members who believe they are being underpaid and a very hostile economic environment (Matsikidze, 2011). Organisations in Zimbabwe are also facing difficulties in rewarding competitive salaries in the dollarized economy and this situation has been worsened by NEC negotiating exorbitant minimum wages which are not linked to productivity per se. Organisations are therefore fighting to manage costs and the increasing labour costs are not making it easier for them. The confusing messages that came out of the inclusive government regarding economic issues, political issues and the holding of elections were not improving the situation especially in attraction and retention of skills and productivity (Matsikidze, 2011). Based on such an environment the two sectors are battling to make strategic reward management choices that will enable them to retain their employees and attract prospective employees. Public sector organisations have more formal procedures for decision making and are less flexible and the private sector has less formal procedures and is more flexible (Farnham, 1995). For the public sector the multiplicity of its objectives, the complexity of measuring performance and the tendency to conflict between its different goals and stakeholders makes it more difficult to make a strategic reward choice (Child, 2000). According to Nutt (2005: 5) cited in Armstrong (2009) "the external environment of organisations is littered with political considerations." The bureaucratic nature of the public sector gives control to a lot of individuals which also constrain the strategic reward choices as it has to consider the interests of various publics as compared to the private sector. Developments by the then Minister of Finance Mr Biti such as imposition of stricter budget controls coupled with his thinking that "we eat what we gather" which is synonymous with productivity bargaining has also had an impact on the strategic reward choices that the public sector is making (Matsikidze, 2011).

On the other hand the goal of private sectors is to make profits, they are revenue oriented and this is what determines their rewards. However with employee associations negotiating high wages for them private 
universities are forced to reward employees without matching it to productivity at the same time the employees are not even satisfied by those wages; they want more. Like Nutt (2005) as cited in Armstrong (2006) states "Environmental constraints for private sector managers arise mostly out of natural interaction of market forces..."

A reward is a strategic tool for gaining competitive advantage by leveraging employee attraction and retention. Most human resource problems arising in Zimbabwe now are related to rewards which are failing to retain employees as compared to those offered by other countries like South Africa. The problem is therefore based on the reward choices being made by the public and private sectors. Thus there is need to realise whether these strategic choices are being influenced by the Zimbabwean environment and its impact on the two sectors or not. Therefore there is need to compare the strategic choices the two sectors are making and understand the factors influencing them. The aim is to identify and compare the factors affecting reward choices in the public and private sector and the environmental challenges they are facing in implementing these rewards.

The research is theoretically guided by the contingency approach and the stakeholder theory. Contingency models link the particular strategies (reward) adopted by the organisation to the particular aspects of the business environment (Beardwell, 2004). The contingency approach emphasises the importance of ensuring that human resource strategies(reward) are situational to the circumstances of the organisation including its culture, operational processes and external environment arguing that they become more efficient when linked/tailored to the surrounding context or environment of the business (Armstrong, 2009). Reward choices are informed by particular contexts and the limited range of managerial behaviour that may be available in the context, the sectors then chose those strategies that fit their external environment and internal environment (Armstrong and Duncan, 2008). When designing the total rewards system, stakeholders' concerns must be taken into consideration in order to ultimately create the most effective system meaning strategic decisions are dependent on stakeholders' interests. As such the stakeholder theory was also used to inform the research. It is grounded on the idea that sound choices are not limited to meeting objectives of shareholders but other interest groups with a stake in the company. In this case the needs and wants of employees in terms of rewards should be compatible with what the organisation will be offering and what the society views as appropriate.

\section{Research Methodology}

The research took a comparative approach and aimed at making comparisons between the private and public sector. The research was mainly qualitative however some quantitative techniques were used in the data presentation. Purposive sampling was used where the researcher selected targeted managerial and non managerial employees to answer the research questions. These employees were purposively sort out due to the vital information which they held and the nature and positions of their jobs and work. This was used hand in hand with the snowballing technique which involved finding a few people who were relevant for the study in question who made use of their social networks to refer the researcher to other people who contributed to the study. People chosen were those in HR and workers representatives these then referred the researcher to other individuals with more information. This was more appropriate as the researcher had limited time and resources. This assisted the researcher to gain more access to the information which was restricted to a few individuals.

The sample size was 84 respondents, 49 from the public sector university and 35 from the private sector university.

Table 1. For public university

\begin{tabular}{lll}
\hline Category & Target population & Actual \\
\hline Middle managers & 8 & 7 \\
First line managers & 13 & 13 \\
Shopfloor employees & 29 & 29 \\
Total & 50 & 49 \\
\hline
\end{tabular}


Table 2. For private university

\begin{tabular}{lll}
\hline Category & Target population & Actual \\
\hline Middle managers & 8 & 4 \\
First line managers & 13 & 10 \\
Shopfloor employees & 29 & 21 \\
Total & 50 & 35 \\
\hline
\end{tabular}

The research used both primary and secondary sources of data through the use of semi-structured interviews for managers, focus group discussions for non-managerial employees and questionnaires for non managerial employees who were not in the focus group discussions. The semi-structured interviews allowed flexibility and did not restrict the field of inquiry of the researcher. 14 interviews were held for each of the universities. Interviews gave room to the interviewer to elaborate and explain the questions where misunderstandings arose. 4 Focus group discussions of six to ten people were held with administrative staff . The other focus group discussion was held with academic staff that is lecturers in the public sector university. Focus group discussions were used at the public sector university and questionnaires were used at the private sector university. The researcher intended to use focus group discussions at the private sector university but questionnaires instead of focus groups were used due to the challenge of time, gaining access and aspects of anonymity since respondents were not comfortable divulging information to the researcher. Some workers were also too busy to be interviewed thus questionnaires gave them room to contribute to the research by completing the questionnaire during their free time. These questionnaires were in the form of both closed ended questions which allowed the respondents to tick the category that best described their response and open ended questions and sections which allowed the respondents to express their true perspectives. 21 non managerial employees responded to questionnaires in the private sector university.

Secondary sources where HR reports, exit interview reviews, written documents, company policies and procedures. To present the data a narrative and descriptive approach was used with the use of tables. The research used thematic analysis which involves taking one piece of data and comparing it with all others that may be similar or different in order to develop conceptualisation of the possible relations between various pieces of data. (Bickman, 2009).

\subsection{Data Presentation}

Table 3. Characteristics of respondents in the public university

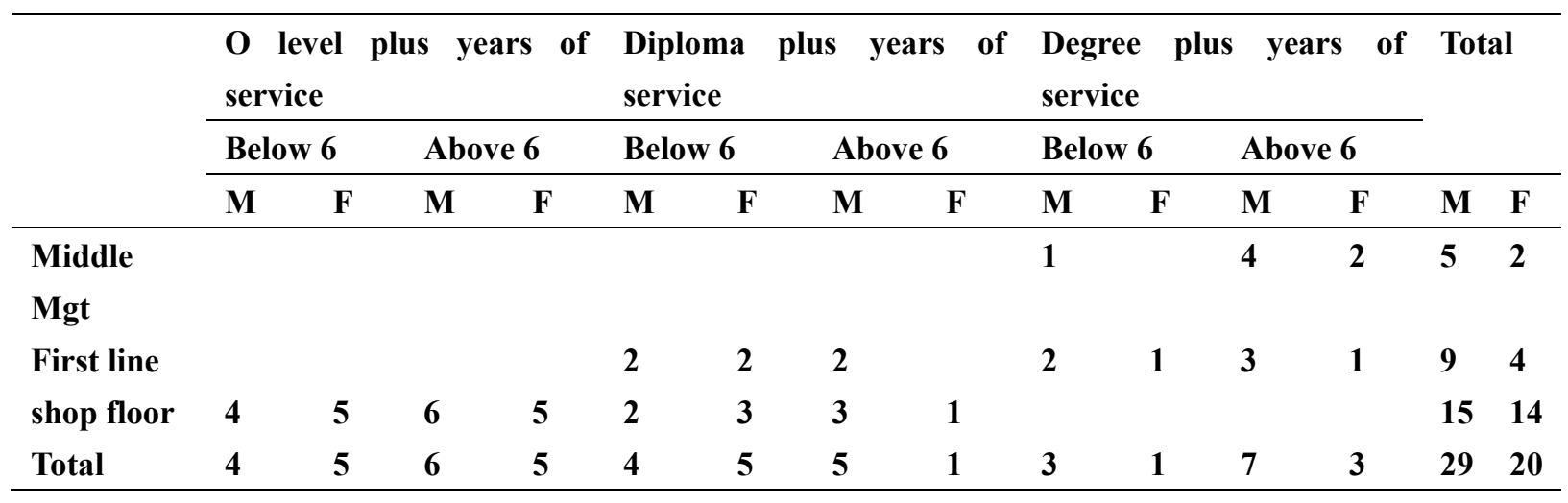


Table 4. Factors that influence reward choices in the public sector

\begin{tabular}{ll}
\hline EXTERNAL FACTORS & INTERNAL FACTORS \\
\hline Political & Costs \\
Government & Top Management \\
Competition & Students \\
State university & Workers unions \\
Zimbabwe's' Economy & Employees \\
\hline
\end{tabular}

\subsubsection{External Factors}

One manager from information and public relations cited competition as a great determinant of the reward choices they made as an organisation. She said that the organisation benchmarked regionally so that they could attract and retain key employees. The manager went to explain that locally they had local universities poaching their staff thus they had to pay above market rate. The manager further explained that even regionally their employees were fleeing to countries like Botswana so they had to change their reward choices to make them competitive. One of the worker representatives interviewed supported this aspect also saying that to avoid staff moving from one university to the other they negotiated a wage that was competitive showing that competition was a factor that affected reward choices.

The other external factor highlighted by seven middle managers and eight shop floor employees with "O" levels was the government. Six of the middle managers with degrees interviewed explained that as a public institution the bulk of their salaries came from the government so how they paid was greatly dependent on the government's ability to pay. They said the government set the salaries through the ministry of finance and that the university had no discretion whether to pay below or above market. One male manager from HR then said the government thus contributed to the reward choices of the university. He said that because the government had a source of income from the mining sector it was able to increase its salaries to competitive levels.

One aspect of the environment also said to influence strategic reward choices by one male middle manager in the finance department was political factors. He said that when political figures were campaigning they would lobby for an increase in wages, thus political factors had a bearing on choices made.

The other factor pointed out was the fact that the institution was a State University and this alone influenced the organisation's reward choices. To further explain how being a state university affects their reward choices one worker representative explained that they negotiated for funds as a group of state universities in Zimbabwe and this was a disadvantage for the university. So choices were influenced by decisions made at the negotiating forum.

\subsubsection{Internal Factors}

The employee representatives were mentioned by fifteen shop floor workers from all five focus groups held as greater determinants of the organisations' reward choices. In the first focus group held it was discussed that the strength of these associations and their power to negotiate was what had actually made the institution have variable pay in terms of the local incentive. One male employee in particular who had been with the organisation for more than six years stated that the employee bodies played a role in the reward choices made by the institution. He stated that these representatives helped negotiate for the non-removal of the incentive allowance when the university threatened to scrap it off on the basis that the government fixed salaries had improved. Five first line managers and seven secretaries seemed to agree that students were also another internal factor that influenced the reward choices that the organisation had to make. An assistant registrar reflected that students were stakeholders and they were always claiming that the university abuses their funds by paying exorbitant salaries. This has then increased the need to be transparent. A middle manager from students' affairs explained that to increase this transparency they had a student body SRC that was there to question and understand the universities actions and complain if they thought funds were being abused. In the first focus group with the lecturers it was also discussed that the students' numbers had a bearing on variable pay (allowance for teaching parallel students) for this could only occur if these students were present. To shed more light on this aspect an administrative assistant from HR was asked what the university considered when making reward decisions and he mentioned ability to pay especially for the local incentive. He further stated that this ability to pay was highly dependent on how the students paid their fees as this was the major source of income for the university. 
In a fifth focus group discussion of seven people with the IT department, top management was cited as one of the internal factors that determined the organisations reward choices. An administrative assistant from public relations also raised a point in the same line of thought explaining that when for example making decisions in relation to the local incentive the top managers met and decided on whether to increase the incentive or not basing on the capability and productivity of the organisation. Therefore the discretion was of top management.

Table 5. Characteristics of respondents in the private university

\begin{tabular}{|c|c|c|c|c|c|c|c|c|c|c|c|c|c|c|}
\hline & \multicolumn{4}{|c|}{$\begin{array}{l}\text { O level plus years of } \\
\text { service }\end{array}$} & \multicolumn{4}{|c|}{$\begin{array}{l}\text { Diploma plus years of } \\
\text { service }\end{array}$} & \multicolumn{4}{|c|}{$\begin{array}{l}\text { Degree plus years of } \\
\text { service }\end{array}$} & \multirow{2}{*}{\multicolumn{2}{|c|}{ Total }} \\
\hline & \multicolumn{2}{|c|}{ Below 6} & \multicolumn{2}{|c|}{ Above 6} & \multicolumn{2}{|c|}{ Below 6} & \multicolumn{2}{|c|}{ Above 6} & \multicolumn{2}{|c|}{ Below 6} & \multicolumn{2}{|c|}{ Above 6} & & \\
\hline & M & $\mathbf{F}$ & $\mathbf{M}$ & $\mathbf{F}$ & M & $\mathbf{F}$ & M & $\mathbf{F}$ & $\mathbf{M}$ & $\mathbf{F}$ & M & F & M & $\mathbf{F}$ \\
\hline middle Mgt & & & & & & & & & 1 & & 2 & 1 & 3 & 1 \\
\hline First line & & & & & 1 & 2 & 1 & & 2 & 1 & 2 & 1 & 6 & 4 \\
\hline shop floor & 2 & 4 & 4 & 3 & 2 & 2 & 3 & 1 & & & & & 11 & 10 \\
\hline Total & 2 & 4 & 4 & 3 & 3 & 4 & 4 & 1 & 3 & 1 & 4 & 2 & 20 & 15 \\
\hline
\end{tabular}

Table 6. Factors affecting reward choices in the private sector

\begin{tabular}{ll}
\hline External factors & Internal factors \\
\hline Financial consultancy & Organisational capabilities \\
Competition & Costs \\
Zimbabwe's economy & church \\
The government & Students \\
& employees \\
\hline
\end{tabular}

\subsubsection{External Factors}

Ten out of twenty one shopfloor employees listed the financial consultancy as one of the major factors that influenced the university's reward choices. The consultancy advices the university on how best to reward its employees and it informed them of their position in the market. Three administrative assistants also mentioned this financial consultancy as a major factor.

The other external factor that influences reward choices in the university that was identified was competition. A manager with an HR background explained that the university had a reward policy of paying $24 \%$ above the state universities so their rewards would be competitive. He went on to state that they had not been able to do that of late because of the changes in the environment particularly the dollarisation of the economy. The assistant registrar HR also concurred and further stated that the aim of the university was to attract talent from the whole of Africa. To achieve this they had to benchmark basing on their competitors' rewards. Three clerks also cited competition as a factor though in the follow up comment they stated that this was ceasing to be a factor since the rewards of the organisation were not taking into account the reward choices of competitors.

In the review document used by the researcher as a secondary source the economic situation of Zimbabwe was another external factor that was identified. It was written that due to economic instabilities in the country the university was failing to cope and maintain its position in the market. The document explained that before the inflationary era the institution was able to pay competitive salaries but during the inflationary period and the subsequent dollarisation the university failed to cope.

An IT manager cited the government as a factor that influenced reward choices though to a lesser extent. Government continuously increased salaries for State universities making it difficult for the private university to match that. At the same time the fact that it was a private university and not a state university meant it could not get financial assistance from the government making it difficult for it to pay above market rate.

\subsubsection{Internal Factors}

Organisational capabilities were the greatest internal factor identified by twelve respondents as influencing its 
strategic reward choices. They cited affordability and ability to pay. One manager from the bursar's department said that since they did not have funding from elsewhere their reward choices were mainly based on their ability to afford those choices. As their competitors continuously increased their rewards and improved their choices, their university could not afford to do that.

Costs were also identified as a major factor that influenced the strategic choices of the organisation. It was pointed out by one assistant from the accounts department that depending on the costs of the organisation in relation to revenue that it would be getting from the farm and students fees then the organisation would see if it could improve rewards. Therefore the higher the cost without revenue changing meant the organisation would focus on cost cutting and they would start by cutting labour costs since these constituted the higher percentage of their total costs.

The universities prospectus revealed that the funding for the private university was a two-part effort. Some funds were apportioned to them by the church. The apportioned dollars provided for the day-to-day operating expenses of the university. The second half was raised through World Service Special Gifts for a permanent endowment. The interest and earnings on the permanent endowment provided for scholarships and other financial aid for students as well as met new and emerging programmatic needs of the university. One of the lecturers also identified the church as an internal factor that influenced the rewards but not to a greater extent. The lecturer explained that the university was founded by the church and was funded by the church however it was being "weaned" off. However, whenever the University faced great financial challenges the church chipped in financially so as to try and improve its position in the market.

An assistant from student affairs indicated that the ability of students to pay school fees set by the university and paying on time also affected the reward choices of the university. As Zimbabwe was now using the United States dollar it had become a challenge for most foreign and local students to afford their school fees therefore payments had become inconsistent and this affected the university and its enrolment rate had decreased due to that. The assistant also pointed out that their fees were higher than most universities pegged at \$US2500.

Employees were also mentioned by the HR assistant as an internal factor that affected rewards. He said that when the university was facing high levels of labour turnover it improved its reward strategies and when employees threatened to strike the University improved the rewards showing that employees had a great influence on the reward choices made by the university.

\section{Discussion}

\subsection{Factors That Influence Reward Choices}

\subsubsection{External Factors}

One of the factors identified as an external factor was the political factor. Research showed that political figures when campaigning sometimes used increment in rewards as a way to gain support. Armstrong and Cummins(2011) Identified that the effectiveness of reward choices for public sector is hinged upon political support which is characterised by higher controlling bodies that would be having agendas to benefit their own constituencies. This is supported by the research findings that as political figures were campaigning they used rewards as a tool and this aspect about the environment would reflect positively on the public sector as they would have funds availed to them. This was also propounded by Thorpe and Homan (2000) who stated that some reward choices for public sector were a result of political rather than market conditions. This is in line with the stakeholder theory that states that there are other parties (political figures) involved who influence organisation's decisions. The source of funds for the Private sector University was highly student fees and when campaigning political figures would sometimes put restrictions on the amount of fees the university could charge on students and this would mean that they would not be able to reward their employees' competitive rewards. This showed that political figures had an impact on reward choices indirectly in private sectors.

Both universities identified the government as a factor that affected their reward choices. For the public sector university it was because the government was the sole financier of the rewards. The government therefore was a stakeholder to both universities because the rewards they both paid were contingent upon the governments' actions. For the public sector university which is state owned to be able to pay the competitive rewards that it was paying it was because the government was able and willing to pay such salaries. To show that their rewards were highly dependent on the government the public sector university during the hyperinflationary era of Zimbabwe was paying petty rewards because it did not have a source of foreign currency whereas the private sector university though not very competitive its rewards where better because it could get foreign currency from its foreign students. Bratton and gold (1994) stated that the government had a direct and indirect impact on 
reward management. The Government as it continuously increased salaries for State universities made it difficult for the private university to match that. At the same time the fact that it was a private university and not a state university meant it could not get financial assistance from the government making it difficult for it to pay above market rate.

During the inflationary period the public sector university experienced a flight of employees leaving for the private sector university and yet the opposite was now occurring. This was clear evidence to show that the environment affect reward choices. The private Sector University was now failing to pay competitive salaries because it did not have donors and was lagging behind by a great margin as government continuously increased salaries in state universities making it impossible for the private sector university to keep pace. Kotler (2000) propounded that organisations under market positioning might choose to lag behind because they cannot afford the market rate. This is true of the private sector university whose initial choice for market positioning was above market rate but due to its environmental circumstances where they were competing with the government they had chosen to lag behind since they could not afford the competitive salaries. The government through the Minimum Wage Act also informed the private sector university on the rewards they where to make. So even if they chose to lag behind, the amount they would pay had to be above the minimum wage stated by the government. Armstrong and Duncan (2008) pointed out that the government had passed a raft of employment legislation in its quest for both social justice and economic efficiency which had forced organisations to comply. This means that reward strategies are informed by the legislation set by the government.

Another factor that was identified to influence reward choices especially in relation to transparency and equity was the fact that one is a public sector and the other is a private sector. Farnham (1995) in his organisational typology by orientation and ownership showed that the choices made by organisations are highly dependent on who owns them. The research showed that the public sector university as a public institution when it came to transparency it did not have much choice but to be transparent. The private sector university was not pressured to be transparent. This shows that both private and public sectors operate in different contexts (environments) that generate distinctive constraints on their behaviours and choices. The other university being a public institution its structural contexts were different from the private university thus influencing their choice for example whether to be transparent or not. Freeman and Mcvea (2002) stated that the difference in structure and formalisation between the private and public sector led to fundamentally different approaches to rewards. This then supports what the researcher found during the research that the difference in the environments of the two universities caused a difference in their reward choices.

Competition was another factor identified by both universities as an external factor that affected their reward choices. Their competition was constituted of state universities, private universities within Zimbabwe, those universities in the southern region of Africa and with other organisations within Zimbabwe and outside which were not specifically universities for example Econet. Bhatia (2003:26) pointed out that for organisations to choose a reward they should gather information about their competitors rewards as well as those organisations in the same regions that they operate in. One manager in the public sector university from information and public relations cited competition as a great determinant of the reward choices they made as an organisation. She said that the organisation benchmarked regionally so that they could attract and retain key employees Due to the fact that organisations wanted to pay competitive rewards that would allow them to attract and retain their employees they had to consider competition as an environmental factor. The private University tried to benchmark as their reward policy stated but they were failing to match their competitors. Under competition the environmental aspects of the labour market that the organisations were operating in where there was more demand than supply of highly qualified personnel that could become lecturers like $\mathrm{PhD}$ holders affected their reward choices. Armstrong and Duncan (2008:78) saw that the competition in the labour market remained tough and demand for skilled people outstripped supply such that to survive organisations had to be employer of choice. Therefore in order to attract and retain employees' organisations had to take note of the human capital theory and reward those individuals that had invested more in education by changing their reward choices to be above market rate (competitive) as a retention strategy so that they could be able to compete with others. Ulrich (1997) suggested that environmental and contextual changes present a number of competitive challenges to organisations which means HR has to be involved in helping build new capabilities and that can be done through reward choices. Therefore activities that occur in the labour market are environmental factors that can affect reward management.

The economic situation of Zimbabwe was one of the factors that affected the reward choices of both universities. Armstrong and Duncan (2008:73) stated that the strategic reward choices are underpinned by the rate of growth in the economy. They further mentioned that it is no coincidence that the public sector had closed the gap with the private sector because of sustained government investment whereas the private sector was facing shaky 
consumer demand and intensifying international competition. This could be true for these two universities. For the public sector university the government had been able to award higher rewards because of its sustainable investments in mining whereas the private university was struggling. Demand for the private universities' services at the rate of their fees and the economic situation had decreased and as an international university it faced international competition also. The changes in the Zimbabwean economy had thus worked favourably for the public than private sector that is why it was now left for the private sector to match salaries in the public sector when the norm was the public sector lagging behind.

\subsubsection{Internal Factors}

Both universities identified students and employees as part of the internal environment that influenced their reward choices. It was highlighted that in wanting to pay more rewards to employees the private university had to increase its fees, however, the students would also complain on the continuous increase in fees to pay employees. The public University however increased numbers through parallel and visiting programmes and these extra classes brought more income. This aspect agrees with the theoretical framework of the research which is informed by the stakeholder theory. The theory postulates that reward choices are not limited to meeting objectives of one stakeholder but there are other stakeholders to consider. In this case as the universities want to satisfy employees by giving them higher rewards they have to consider the students' capability to pay fees as well. The private sector highlighted that as Zimbabwe was now using the United States dollar it had become a challenge for most foreign and local students to afford their school fees therefore payments had become inconsistent and this affected the university and its enrolment rate had decreased due to that. One assistant also pointed out that their fees were higher than most universities pegged at \$US2500 where as the public sector was at $\$ 700$. This meant students could not pay fees thus no income for salaries.

According to Johnson, Schools, Whittington (2006:18) “ strategic choice as a process involves understanding the nature of stakeholders expectations, thus having a fit between the economic, social goals of the organisation, expectations of stakeholders and societal needs". For both universities their economic goals were to make enough to survive since they both were not profit making organisations. As for their social goals they both were aiming to serve and benefit the community in providing education for all and creating forums for Zimbabweans to get a chance to education one being a state university and the other a church university. Farnham (1995) agreed with this when he came up with his organisational typology which states that an organisations orientation determines its goals objectives and actions. Therefore these universities since they have welfare and community goals it means they will consider both the employees and students when making their reward choices. At the same time their employees as stakeholders expect to be paid competitive rewards and students expect reasonable fees. This therefore highlights that their internal environments and their stakeholders are what determines their reward choices as they want to assure that their employee needs and wants are compatible with the societal view and students needs and wants. Freeman et al (2002) postulated that in a world of turbulent and accelerating change the interests of key stakeholders must be integrated into the very strategic reward choices of organisations. This therefore agrees with the research that the environment (stakeholders) has an impact on the reward choices made by organisations.

Another environmental factor that was identified by the public sector university was the presence of employee associations. Bhatia (2003:1) stated that the bargaining power of unions also influenced reward choices. If these associations fail in negotiations they resorted to strike and other methods that restrict labour supply. This exerted a kind of influence on the employer to concede at least partially to the demands of the association. The employee representatives from the public sector were mentioned by fifteen shop floor workers from all five focus groups held as greater determinants of the organisations' reward choices. In the first focus group held it was discussed that the strength of these associations and their power to negotiate was what had actually made the institution have variable pay in terms of the local incentive. This aspect explains why there was a difference in reward choices between the two universities as the public sector university had these associations and the private university did not have. This can be attributed to the fact that the public sector university could be forced to improve its reward choices because of pressure from employee associations and threats of strike action whereas Private Sector University did not have such undue influence. This is in line with the contingency theory that situational factors influence reward choices, the situational factor here being the presence or absence of employees associations.

Costs of the organisation in relation to revenue were one of the internal factors identified by the universities as affecting their reward choices. It was explained that the funds the organisations had were not enough as the administrative costs and labour costs were high. In an effort to control costs, the organisations could not afford to pay competitive salaries to its employees. It was pointed out by one assistant in the private university from the 
accounts department that depending on the costs of the organisation in relation to the revenue that it would be getting from the farm and students fees then the organisation would see if it could improve rewards. Therefore the higher the cost without revenue changing meant the organisation would focus on cost cutting and they would start by cutting labour costs since these constituted the higher percentage of their total costs. Therefore, for the private sector university they could not afford to pay above market rate and the public sector university could not afford extra benefits. Bhatia (2003:10) also identified organisations capacity to pay as a factor that influenced reward choices. Hicks Marshall in his fourth law of derived demand in labour economics stated that the choices made by organisations are dependent on the proportion of the cost of labour and the total cost of operating the business. This showed that the total cost of running the business would determine the reward choices of the business.

Top management was also an internal factor identified as influencing the reward choices of the organisation. For the public sector university in a fifth focus group discussion of seven people with the IT department, top management was cited as one of the internal factors that determined the organisations reward choices. An administrative assistant from public relations also raised a point in the same line of thought explaining that when making decisions in relation to the local incentive the top managers met and decided on whether to increase the incentive or not basing on the capability and productivity of the organisation. For the private sector university since it did not have a negotiation forum, salary determination was the management board's prerogative. Armstrong and Brown (2008) stated that top management had a crucial role to play in reward management. This was because they were the ones who determined rewards meaning that different management environments within organisations could result in different reward strategies. Bhatia (2003:134) also clearly highlighted that reward management is dependent on the deliberate decision of management whether to be a leader or to trail in the market. This is in line with the contingent theory which states that organisations will come up with reward choices depending on their internal environment. In this case both universities came up with rewards highly dependent on the discretion of top management. Johnson, Scholes and Whittington (2005:594) also stated that it is the role of top management to set strategies and be the detailed planners of strategy. This agrees with the fact that top managers are part of the internal factors as they are the ones who set the reward strategies.

\subsection{Challenges}

One of the challenges identified was in relation to the negotiating forum which determined their funds where the public sector university was not able to negotiate on its own but with other universities thus had to share the apportioned funds with others. One worker representative explained that they negotiated for funds as a group of state universities in Zimbabwe so choices were influenced by decisions made at the negotiating forum. Such an environment restricted choices made by the university. This is what Armstrong (2006) said that the budget process for public sectors was not flexible and that it had to accommodate so many ministries that it was difficult for them to negotiate as individual ministries or sections of the ministry. Such an environmental factor therefore affected the reward choices that MSU made.

The private sector universities' challenge was that they did not have a stable source of finance as they had to rely on students who were not consistent in paying their fees. The church to a certain extent would assist but it was not predictable how much they would get as there were other sections of the church that it also had to support other than the university such as orphanages and high schools. The source of funds for both universities therefore made it difficult for them to negotiate for additional funds which would be critical for them to make the reward choices they wanted. Matsikidze (2011) rightly pointed out that in the prevailing Zimbabwean economic environment the two sectors were facing a plethora of challenges especially related to finding money for sustainability and to reward staff who were convinced they were underpaid. From the above it is obvious that this aspect of the environment was a challenge for both universities in the reward choices they wanted to make and even in maintaining the ones they had chosen so as to attract and retain the desired calibre of employees.

Both universities cited one of their challenges to be student failure to pay school fees. In a newspaper article from the Manica post (2011) it was said that the economic climate of Zimbabwe was making it difficult for some students from the private sector university to pay their fees and continue their education without further scholarship and financial aid assistance. At the same time this was the source of finance that the organisation relied on to get funds for their rewards. The universities have had to put measures in place and emphasise the need to collect meaningful fees from students because they were committed to giving them an education that was of high quality. The universities had to be able to retain its lecturers with appropriate salaries and benefits, maintain and improve its facilities, and provide a good environment for the students and if students and their families did not contribute through fees, then they would have a broken-down system. The universities however had since realised that as they put pressure for fees more students were deferring and some were withdrawing their studies which 
worsened their situation since the decrease in enrolled students also decreased the revenue for the universities. Therefore this challenge of students as stakeholders and contributors to fees structures affected the reward choices for the two universities.

To demonstrate impact of students' inability to pay fees in the public sector lecturers got an allowance for teaching parallel classes and this allowance was funded by tuition fees. When the students could not pay on time the university also found it difficult to pay the lecturers on time which created inconsistencies and low levels of equity where lecturers would feel their effort was not rewarded. Armstrong and Duncan (2008:76) highlighted that as the dynamics of the business changed the reward choices also changed therefore as the dynamics for these universities changed they were forced to also change their rewards to suit the new dynamics.

The other challenge identified by the private sector university was inability to pay and reward competitively. Respondents from the private university pointed out that the limited programmes that the university offered and the limited modes of study was also a challenge for them as it compromised their source of finance which ultimately restricted their reward choices. This could have contributed to the private university paying below market rate in comparison with the public university which had multiple sources of finance including programmes such as visiting classes, parallel classes, bridging and block release classes. These differences in programs offered at both universities explained the different reward choices. Despite this fact the public university could not afford to offer lucrative benefits because they had a lot of developments which they were doing as a university which meant their budget was strained so even though they could pay above market rate they could not afford the extra benefits that employees would prefer. This conforms to Armstrong et al (2006) assertion that cost pressures can particularly lead to a challenge on the reward approaches chosen by organisations. Which was the same argument propounded by Hicks Marshall that the total costs of the business compared to revenue would determine reward choices.

\section{Conclusion}

Reward choices today are much more complex, they are more than alignment with business strategy but there is need to take into account the broader economic context, legislative environment, labour market and the internal environment. Balancing these environmental aspects is an appropriate touchstone for success for strategic reward choices.

The major findings of the research indicated that the environment both internal and external that an organisation would be operating in did influence the reward choices. Findings also showed that some factors of the environment affected the private and public sector differently thus resulting in different strategic choices for example the government. This confirmed the theoretical framework that reward choices were contingent upon the environment and that stakeholder concerns were taken into consideration when choosing strategies. Contrary to the popular belief that private sectors had better reward choices than public sectors the research revealed that in the prevailing environment public sectors are awarding better rewards than private sectors.

\section{Recommendations}

Environmental factors have proved to be crucial/ essential in making strategic reward choices for most organisations worldwide. For rewards to be effective they have to take into consideration the internal and external environment. For both universities to be successful they also need to take note of the following recommendations.

1) For the public sector university though it has been able to respond positively to the environment and it is paying competitive salaries it is important to note that there is more to motivation than financial rewards. This means that they have to apply the total reward model. This is the combination of financial and non financial rewards. These non-financial aspects can include recognition, praise and thanks and job security.

2) The public sector university should also be able to manage perceptions of its employees so as to build feelings of equity and fairness. It can make use of Adam's equity theory which states that perceptions of employees are what cause feelings of inequity. This means that it has to come up with interventions to create awareness and communicate with employees so as to manage these negative perceptions.

3) The private University also identified funds as a challenge it faced. To counter this challenge it needs to take initiative and benchmark against what their competitors are doing to improve their sources of funds. It should also introduce such programmes as visiting, block release and parallel so as to attract a wider base of clients which will then improve their source of funds. It also needs to improve the number of programmes it offers and not limit itself.

\section{References}

Armstrong, M, (2009). A Handbook Of Human Resource Management Practice (1th ed.). Kogan Page, London. Armstrong, M., \& Brown, D. (2001). New Dimensions in Pay Management. 
Armstrong, M., \& Brown, D. (2008). Strategic Reward Making It Happen. Kogan Page, India.

Armstrong, M., \& Cummins, A. (2011). The Reward Management Toolkit. Kogan Page, Britain.

Armstrong, M., \& Murlis, H. (2005). Handbook of Reward Management. Kogan Page, India.

Beardwell, I. (2004). Human Resource Management, A Contemporary Approach (4th ed.). Harlow.

Bhatia, S. K. (2009). New Compensation Management in Changing Environment. Deep And Deep Publications, India.

Bickman, L. (2009). Social Research Methods. Sage Publications, London.

Bratton, J., \& And Gold. J. (1994). HRM Theory and Practice. Macmillan Press, London.

Bussin, M. (2011). The Remuneration Handbook For Africa. Knowress, South Africa Chartered Institute Of Personnel Development, London.

Evans, N., Campbell, D., \& Stonehouse, G. (2003). Strategic Management. Amsredam, Butterworth Heinemen.

Farnham, D., \& Pimlott, J. (1995). Understanding Industrial Relations. Cassell, London.

Freeman, E., \& Mcvea, J. (2002). Journal of Shareholder Approach to Strategic Management. Oxford.

Ivancevich, J. (2004). Human Resource Management (9th ed.). Mcgraw Hill, Boston.

Jonhson, G., Schools, K., \& Whittington, R. (2006). Exploring Corporate Strategy (7th ed.). Pearson Educated, England.

Kenworthy, P. (2008). Reward Strategy (3rd ed.). Hr, London.

Lawler, E. (1990). Strategic Pay. Jossey Bay, San Francisco.

Manica Post. August 2011.

Matsikidze, R. (2011). IPMZ Labour Briefing.

Maund, L. (2001). An Introduction to Human Resource Management Theory and Practice. Palgrave, New York.

Morris, D., \& Maloney, M. (2004). Strategic Reward Systems: Understanding the Difference between 'Best Fit' and 'Best Practice'.

News Day. November 2011.

Phillip, K. (2002). Principles of Marketing (2nd ed.). Prentice Hall, Europe.

Richard, T., \& Gill, H. (2000). Strategic Reward Systems. Pearson Education, Engaland.

Stringer et al. (2011). Motivation, Pay Satisfaction and Job Satisfaction of Front Line Employees.

Torrington. (2005). Human Resource Management (6th ed.). Pearson Educated Limited.

World At Work. (2006). Journal on Total Rewards Model, Fortune Magazine.

\section{Copyrights}

Copyright for this article is retained by the author(s), with first publication rights granted to the journal.

This is an open-access article distributed under the terms and conditions of the Creative Commons Attribution license (http://creativecommons.org/licenses/by/3.0/). 